\title{
EFFECT OF SOME COMPONENTS OF VOLATILE OILS, SODIUM CARBONATE AND BICARBONATE FOR CONTROLLING BLUE AND GREEN MOLDS OF Lime (Citrus aurantifolia) FRUITS DURING STORAGE Abd-El-Aziz, Shadia A. *and A. A. Dewidar ${ }^{* *}$ \\ * Plant Pathology Res. Institute, Agric. Res. Center, Giza, Egypt \\ ${ }^{* \star}$ Horticulture Res. Institute, Agric. Res. Center, Giza, Egypt
}

\begin{abstract}
Blue and green molds caused by Penicillium italicum Wehmer and Penicillium digitatum Sacc. are the most important diseases affecting lime fruits. Some component of volatile oils i.e. limonene, linalool, citral and nerol were extracted from orange peel, coriander seed, lemon grass and petitgrain (Bitter orange) respectively, and were tested for their effect on linear growth of $P$. italicum and $P$. digitatum. Nerol and citral at $0.4 \%$ showed $100 \%$ reduction of linear growth. Sodium carbonate (SC) and sodium bicarbonate (SBC) showed complete inhibition on linear growth of the tested fungi at the concentration $2.0 \%$.

Effects of citral and SC or SBC singly or in combination for controlling blue and green molds of lime fruits were studied. The most effective treatments were the combined treatments between citral at $0.5 \%$ and SC or SBC at $2.0 \%$ which completely inhibited disease severity for blue and green molds of lime fruits under artificial infection and during storage for three weeks at $13 \pm 1^{\circ} \mathrm{C}$. However under natural infection, the combined treatments with citral at $0.5 \%$ and SC or SBC at $2 \%$ completely inhibited percentages of infection during storage for three weeks. All treatments decreased the loss of fresh weight of lime fruit and vitamin C content but total soluble solids increased.
\end{abstract}

Keywords: Blue mold, green mold, lime fruits, some component of volatile oils, sodium carbonate and bicarbonate,

\section{INTRODUCTION}

Green and blue molds, caused by Penicillium digitatum Sacc. and $P$. italicum Wehmer are the most damaging postharvest diseases of citrus fruits. Postharvest decay of lime fruits caused by $P$. digitatum and $P$. italicum are important postharvest storage problems (Smilanick and Arruf, 1992). Volatile oils of citrus or their constituents are shown to have a fungicidal activity against postharvest pathogens of citrus (Caccioni et al., 1998). Also he noted that a positive correlation between monoterpenes other than limonene and sesquiterpene content of the oils and the pathogenic fungi inhibition. Volatile oils or their constituents of citrus fruit show complete inhibition of $P$. digitatum, P. italicum, (Caccioni et al., 1998). The main constituents of volatile oils are mono-and sesquiterpenes and some of these compounds have shown antibacterial, antifungal and antioxidant activities (Lee and Ahn, 1998). Sweet orange (Citrus sinensis L. Rutaceae), contains volatile oil extracted from fruit peels which is characterized by high limonene content, the fruits (seeds) of coriander (Coriandrum sativum,L. Apiaceae) contain volatile oil highly constituted with linalool as a main component. Lemongrass (Cymbopogon citratus (DC.) Stapf., Poaceae) contains mainly citral as a main component of 
volatile oil extracted from leaves (Schaneberg and Khan, 2002) and 1 to $2 \%$ essential oil on a dry basis (Carlson et al., 2001). Bitter orange (petitgrain) oil (Citrus aurantium var. amara, Rutaceae) contains nerol. It showed great inhibitory effect on the linear growth of Alternaria solani (Abd- El-kareem, 2007). Droby et al., (2008) found that citral, exhibited a stimulatory effect to $P$. digitatum at 0.005 and $0.01 \mu \mathrm{l} /$ plate and completely inhibited both germination and germ tube growth above those concentrations while, in $P$. italicum, germination and growth were stimulated at concentrations up to $0.1 \mu /$ plate but were inhibitory at the higher concentrations. Compared to citral, linalool, significantly stimulated germination of $P$. digitatum and $P$. italicum at higher amounts (up to $2 \mu \mathrm{l} /$ plate). Also he found that limonine, myrcene, a pinene and $\beta$. pinene were stimulatory to $P$. digitatum and $P$. italicum but inhibitory to or had no effect on $P$. expansum and Botrytis cinerea.

Treatments with sodium carbonate and sodium bicarbonate provided satisfactory control of green mold of lemons (Smilanick et al., 1997) and blue mold of orange (Palou et al., 2001). Sodium carbonate reduced the incidence of citrus green and blue mold (Palou et al., 2001 and Palou et al., 2009). Latifa et al. (2011) showed that among 28 tested compounds, sodium carbonate, ammonium carbonate, copper sulfate, EDTA and sodium metabisulfate have completely inhibited the mycelial growth and sporulation of $P$. italicum at only $0.02 \mathrm{M}$.

The present study was performed to evaluate the effect of some components of volatile oils (nerol, citral, linalool and limonene) and sodium carbonate or sodium bicarbonate on linear growth of $P$. digitatum and $P$. italicum in vivo and studying in vitro control blue and green molds of lime fruits.

\section{MATERIALS AND METHODS}

Isolates of both Penicillium digitatum and $P$. italicum were isolated from infected lime fruits shown green and blue molds collected from the local market of Sharkia Governorate. For isolation, samples were introduced and carefully washed with running tap water, dried between filter papers and surface sterilized with $1 \%$ sodium hypochlorite for $2 \mathrm{~min}$., then the samples were washed thoroughly with sterilized distilled water for several times and dried between sterilized filter paper. Sterilized samples were cut into small pieces and separately transferred to sterilized Petri-dishes containing potato dextrose agar (PDA) media and incubated for 7 days at $27^{\circ} \mathrm{C}$. Isolates was identified according to Raper and Thom (1968).

\section{Extraction and isolation of volatile oils and its components:}

Four volatile oils which containing the components used in this study i.e. limonene, linalool, citral and nerol were extracted from orange peel, coriander fruits, lemon grass and petitgrain (Bitter orange) respectively using water distillation as described in the British Pharmacopoeia (1963). The Extraction and isolation of volatile oils and its components were carried out at Medicinal and Aromatic Plants Research Department Laboratory, Horticulture Research Institute, Agriculture Research Center, Giza, Egypt. The volatile oils obtained from each sample were analyzed using Ds Chorm 6200 gas 
chromatography equipped with a flame ionization detector for separation of volatile oil constituents. The analysis conditions were as follows:

-The chromatograph apparatus was fitted with capillary column BPX-5, 5\% phenyl (equiv.) polysillphenylene-siloxane $30 \mathrm{~m} \times 0.25 \mathrm{~mm} \mathrm{ID} \times 0.25 \mu \mathrm{m}$ film.

-Temperature program ramp increase with a rate of $10^{\circ} \mathrm{C} / \mathrm{min}$ from 70 to $200^{\circ} \mathrm{C}$. Flow rates of gases was nitrogen at $1 \mathrm{ml} / \mathrm{min}$, hydrogen at $30 \mathrm{ml} / \mathrm{min}$ and $330 \mathrm{ml} / \mathrm{min}$ for air. Detector and injector temperatures were $300^{\circ} \mathrm{C}$ and $250^{\circ} \mathrm{C}$, respectively. The obtained chromatogram and report of $\mathrm{GC}$ analysis for each sample were analyzed to calculate the percentage of main components of volatile oil. Gas chromatography analysis for orange peel, coriander fruits (seeds), lemon grass and petitgrain volatile oils indicating that the content of limonene, linalool, citral and nerol were $91.75 \%, 71.20 \%$, $86.32 \%$ and $4.09 \%$ respectively as shown in Figs. from 1 to 4 .

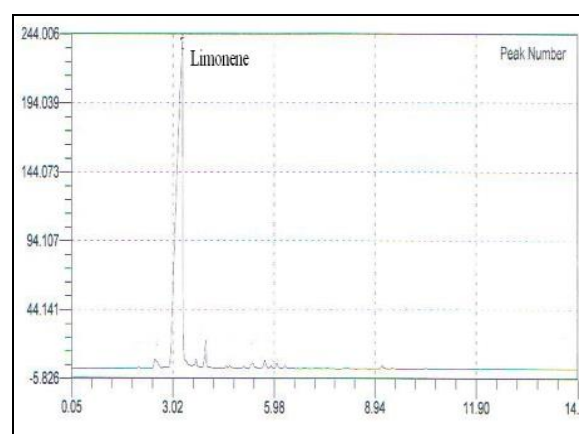

Fig. (1): Gas chromatography analysis for orange peel volatile oil indicating to limonene content $(91.75 \%)$

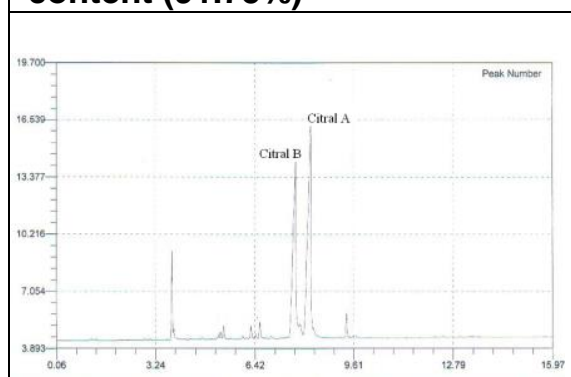

Fig. (3): Gas chromatography analysis for lemongrass volatile oil indicating to citral (citral b+citral a) content $(86.32 \%)$

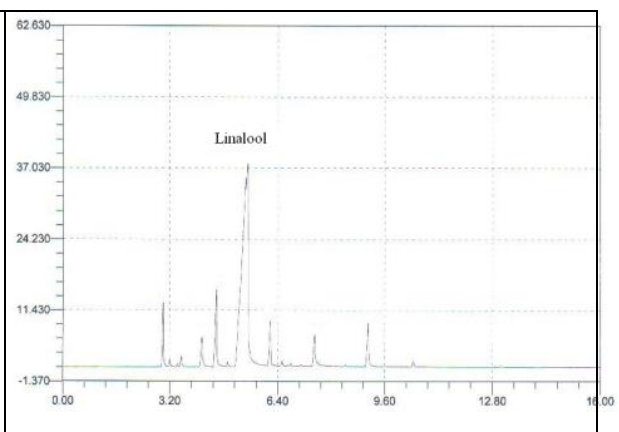

Fig. (2): Gas chromatography analysis for coriander fruits volatile oil indicating to linalool content $(71.20 \%)$

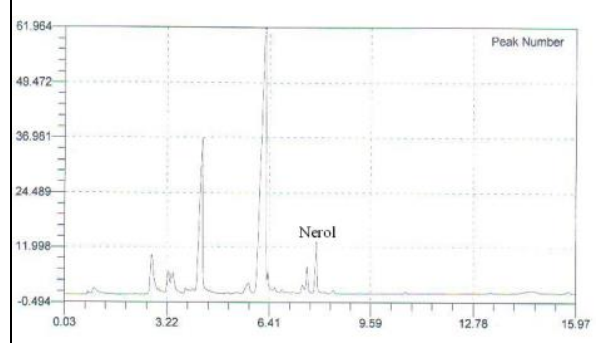

Fig. (4): Gas chromatography analysis for petitgrain volatile oil indicating to nerol content $(4.09 \%)$ 


\section{Abd-El-Aziz, Shadia A. and A. A. Dewidar}

\section{Isolation of volatile oils component:}

\section{Limonene isolation:}

Limonene isolated from orange peel volatile oil into a low density water immiscible solvent (ether). The lower layer is the remaining aqueous distillate evaporation of the solvent to finalize the extraction; the ether layer (boiling .point, $37^{\circ} \mathrm{C}$ ) was evaporated on a water bath to leave the limonene (boiling .point, $\left.176^{\circ} \mathrm{C}\right)$. Distillate limonene $(150 \mathrm{mg})$ obtained from $15 \mathrm{~g}$ of orange peel skin.

\section{Linalool isolation:}

Linalool is the major component of the essential oil of coriander fruits, according to Kamel et al. (2007) linalool can be isolated directly from the essential oil with 2-methyl-butane $(\mathrm{v} / \mathrm{v})$ and dried over anhydrous sodium sulphate. The organic layer was then concentrated, at $30^{\circ} \mathrm{C}$ using a Vigreux column resulting linalool.

\section{Citral isolation}

Citral isolated from lemon grass volatile oil by transferring $3 \mathrm{ml}$ of lemon grass oil, $75 \mathrm{ml}$ of water to a $250-\mathrm{ml}$ round-bottom flask. Place a boiling chip into the flask. Connect the flask to a simple distillation apparatus. Heat the mixture to boiling, carefully at first to avoid excessive foaming, which could spill over into the condenser and into the graduated cylinder, using graduated cylinder to collect the distillate. Isolate the citral obtained from mixture of water and citral by extracting it with diethyl ether; evaporate the ether layer to get citral.

\section{Nerol isolation}

The oil of petitgrain contains primary alcohols and terpene which saponified with the alcoholic potassium a phthalic anhydride. The primary alcohols transformed into acid phthalates or other acid esters of dibasic acids. After purification and saponification with alkali, a geraniol-nerol mixture containing $40 \%$ nerol and $60 \%$ geraniol is obtained. geraniol content is removed by treatment with calcium chloride to geraniol-nerol mixture, in the form of crystalline geraniol compound with calcium chloride, the crystals are removed by filtration. Now, crude nerol as obtained is rectified by dry distillation in vaccuum or steam distillation. The yield of pure nerol will be about 2 to $3 \%$ weight of the petitgrain oil, (NIIR BOARD, 2003).

\section{A- In vitro:}

Effect of component of volatile oils and sodium carbonate or bicarbonate on linear growth of rot fungi of lime fruits:

Antifungal activity of four components of citrus essential oils i.e., Citral, limonene, linalool and nerol and sodium carbonate (SC) or bicarbonate (SBC) were studied by determining their inhibitory effect on growth of Penicillium digitatum and $P$. italicum. Five concentrations i.e 0.1, $0.2,0.3,0.4$ and $0.5 \%$ were tested for each component, Then each concentration was added aseptically to sterile molten PDA medium $\left(45^{\circ} \mathrm{C}\right)$ containing Tween $80(0.5 \% \mathrm{v} / \mathrm{v})$. The resulting media were immediately dispensed into sterilized Petri Plates $(9 \mathrm{~cm})$. In controls, water and Tween 80 instead of volatile oils. 
Sodium carbonate and sodium bicarbonate at five concentrations 0.5 , 1.0, 2.0 and $3.0 \%$ were used. Stock medium of PDA containing the tested concentration was poured into three Petri-Plates after solidification. Three Petri-Plates containing PDA medium without salts were used as control. Discs 3- $\mathrm{mm}$ diameter obtained from 7 day- old of each fungus was aseptically transferred to the center of Petri Plates containing volatile oils, salts and plates served as control. All Petri-Plates were incubated at $25^{\circ} \mathrm{C} \pm$ $2^{\circ} \mathrm{C}$. The average diameter in $\mathrm{mm}$ of each fungus and treated was measured when the fungal growth has covered the check treatment plates.

\section{$\mathrm{B}$ - In vivo:}

Fresh lime fruits cv. Baladi apparently free from physical damage and diseases were washed, disinfected in $0.5 \%(\mathrm{v} / \mathrm{v})$ sodium hypochlorite, rinsed three times in sterile distilled water and then air dried. The effect of dipping lime fruits in citral oil, sodium carbonate and sodium bicarbonate was studied. This was studied in the naturally infected (uninoculated), fruits, as well as in artificially inoculated fruits with Penicillium digitatum and $P$. italicum. lime fruits were wounded with a sterilized needle and inoculation was carried out using a needle, immersed in the spore suspension $\left(10^{6} \mathrm{spores} / \mathrm{ml}\right)$ of each $P$. and $P$. italicum. Wounded fruits inoculated with sterilized water were applied as control. After 24 hours, the inoculated fruits were dipped in sodium carbonate or bicarbonate at $2.0 \%$ as a single. Such treatment was also applied as combined with citral as follows:

\begin{tabular}{|c|c|}
\hline \multicolumn{2}{|c|}{ Treatment } \\
\hline Single & Combined \\
\hline $\mathrm{NaCO}_{3} \quad(\mathrm{SC}) 2.0 \%$ & Citral $0.3 \%+$ SC $2.0 \%$ \\
\hline & Citral $0.5 \%+$ SC $2.0 \%$ \\
\hline $\mathrm{NaHCO}_{3}(\mathrm{SBC}) 2.0 \%$ & Citral $0.3 \%+$ SBC $2.0 \%$ \\
\hline & Citral $0.5 \%+$ SBC $2.0 \%$ \\
\hline $0.3 \%$ & \\
\hline $0.5 \%$ & \\
\hline Control (untreated Fruits) & \\
\hline
\end{tabular}

Control (untreated) was dipped in sterile distilled water. Fruits were dried at room temperature $20 \pm 2^{\circ} \mathrm{C}$. All treated or untreated (control fruits) were placed in a plastic tray in cardboard boxes and stored at $13 \pm 1{ }^{\circ} \mathrm{C}$ for three weeks.

Nerol did not used because it caused bad effect on lime fruits.

Disease assessment:

Percentage of rots disease severity was assessed 1,2, 3 weeks. Disease severity (D.S) was calculated using the scale from $0-4(0=$ healthy, $1=1-25 \%$ infections, $2=26-50 \%$ infection, $3=51-75 \%$ infections and $4=$ $76-100 \%$ infection and formula adopted by Hanounik (1986) as follows:

Disease severity $(\%)=\frac{\sum(\text { NCC } \times \text { CR })}{\text { NTC } \times \text { MSC }} \times 100$

Where: NCC $=$ No. of lime fruits in each class rate. 
NTC $=$ No. of total lime fruits examined

$\mathrm{CR}=$ Class rate

MSC = Maximum disease severity class rate (4).

Infection percentage $\%=\frac{\text { Number of decayedfruits }}{\text { Initialnumberof stored fruit }} \times 100$

Efficacy (E) of each treatment was calculated as follows:

$E=\frac{\text { D.S control- D.S treated }}{\text { D.S control }} \times 100$

\section{Loss in weight:}

Loss in lime fruit fresh weight \% was estimated in uninoculated lime (under natural infection) fruits of various treatments according to the following equation:

Fruit weight loss $\%=\frac{\text { wi }- \text { ws }}{\text { wi }} \times 100$

$\mathrm{Wi}=$ fruit weight at initial period.

Ws $=$ fruit weight at sampling period.

Total soluble solids (TSS):

The percentage of total soluble solids (TSS) was determined by a hand refractometer

\section{Vitamin C (ascorbic acid):}

Extracts from lime fruits were obtained by blending tissues in a blender for 5 minutes containing oxalic acid $6 \%$ equivalent to the tissues $(\mathrm{v} / \mathrm{w})$. The tissues were strained through several layers of cheesecloth. The liquid fraction was then centrifuged for $5 \mathrm{~min}$ at $3000 \mathrm{rpm}$ at room temperature and the filtrate was used to determine ascorbic acid. Twenty $\mathrm{ml}$ of filtrate was brought to volume $100 \mathrm{ml}$ of oxalic acid $3 \%$ and titrated with stain (2, 6- dichlorophenol endophenol) until pink color. Amount of ascorbic acid was calculated according to the following formula, (Jemey and Kovacs, 1968).

Ascorbic acid with milligrams $=\frac{V \times C \times D}{\text { Weight of sample with gram }} \times 100$

Where: $V=$ volume of stain

$\mathrm{C}=$ concentration of stain

Statistical analysis:

$\mathrm{D}=$ dilution of sample.

The data were statistically analyzed using MSTAT-C computer program v.2. 10 (1988).

\section{RESULTS}

Four volatile oils which containing the components used in this study i.e. limonene, linalool, citral and nerol were extracted from orange peel, coriander fruits, lemon grass and petitgrain (Bitter orange) respectively. 
A- In vitro:

Data in Table (1) indicate that all the tested components of citrus essential oil (Citral, limonine, lionalool and nerol), sodium carbonate (SC) and sodium bicarbonate (SBC) at different concentrations have significantly reduced linear growth of Penicillium digitatum. The reduction in growth was correlated to the increase in component of volatile oil, SC and SBC concentrations. All tested components of volatile oil caused $100 \%$ inhibition on linear growth of $P$. digitatum at $0.4 \%$ except limonene who caused $94.4 \%$ reduction of linear growth. Nerol and citral at $0.3 \%$ gave the highest effect on reducing the growth of $P$. digitatum, but limonene gave the least effect at the same concentrations. Also, the used SC or SBC have completely inhibited growth of $P$. digitatum at $2.0 \%$ and at $0.5 \%$ gave least effect on growth of tested fungus.

Table 1: Effect of some components of volatile oil, sodium carbonate (SC) and sodium bicarbonate (SBC) on the linear growth of Pencillium digitatum

\begin{tabular}{|l|c|c|c|c|c|c|c|c|c|c|}
\hline \multirow{3}{*}{ Treatments } & \multicolumn{10}{|c|}{ Cinear growth (mm) } \\
\cline { 2 - 12 } & \multicolumn{10}{|c|}{ Concentration (\%) } \\
\cline { 2 - 12 } & $\mathbf{0 . 1}$ & $\mathbf{R} \%$ & $\mathbf{0 . 2}$ & $\mathbf{R} \%$ & $\mathbf{0 . 3}$ & $\mathbf{R} \%$ & $\mathbf{0 . 4}$ & $\mathbf{R} \%$ & $\mathbf{0 . 5}$ & $\mathbf{R} \%$ \\
\hline Citral & $25.5^{\mathrm{d}}$ & 71.6 & $10.5^{\mathrm{f}}$ & 88.3 & $7.0^{\mathrm{e}}$ & 92.2 & $0.0^{\mathrm{c}}$ & 100.0 & $0.0^{\mathrm{b}}$ & 100.0 \\
\hline Limonene & $45.6^{\mathrm{b}}$ & 49.3 & $27.3^{\mathrm{b}}$ & 69.7 & $10.0^{\mathrm{c}}$ & 88.9 & $5.0^{\mathrm{b}}$ & 94.4 & $0.0^{\mathrm{b}}$ & 100.0 \\
\hline Linalool & $46.0^{\mathrm{b}}$ & 48.9 & $15.0^{\mathrm{d}}$ & 83.3 & $8.3^{\mathrm{d}}$ & 90.6 & $0.0^{\mathrm{c}}$ & 100.0 & $0.0^{\mathrm{b}}$ & 100.0 \\
\hline Nerol & $18.3^{\mathrm{e}}$ & 79.7 & $8.6^{\mathrm{g}}$ & 90.4 & $5.0^{\mathrm{f}}$ & 94.4 & $0.0^{\mathrm{c}}$ & 100.0 & $0.0^{\mathrm{b}}$ & 100.0 \\
\hline & 0.5 & & 1.0 & & 1.5 & & 2.0 & & 3.0 & \\
\hline SC & $30.0^{\mathrm{c}}$ & 66.7 & $13.5^{\mathrm{e}}$ & 85.0 & $9.3^{\mathrm{c}}$ & 89.7 & $0.0^{\mathrm{c}}$ & 100.0 & $0.0^{\mathrm{b}}$ & 100.0 \\
\hline SBC & $45.0^{\mathrm{b}}$ & 50.0 & $20.9^{\mathrm{c}}$ & 76.8 & $12.1^{\mathrm{b}}$ & 86.6 & $0.0^{\mathrm{c}}$ & 100.0 & $0.0^{\mathrm{b}}$ & 100.0 \\
\hline \multicolumn{1}{c}{ Control } & $90.0^{\mathrm{a}}$ & & $90.0^{\mathrm{a}}$ & & $90.0^{\mathrm{a}}$ & & $90.0^{\mathrm{a}}$ & & $90.0^{\mathrm{a}}$ & \\
\hline
\end{tabular}

$\mathbf{R}=$ Reduction

Values having the same letters in the same column are not significantly different at $\mathrm{P}<0.05$

Data in Table (2) show that all the tested components of volatile oils, SC and SBC significantly reduced the linear growth of $P$. italicum. The inhibitory effect on growth was increased by increasing the concentrations. Complete inhibition of linear growth of $P$. italicum was obtained with nerol and citral at $0.4 \%$ which reduced growth by $100 \%$, while the least reduction was obtained with limonine. All concentrations of SC or SBC reduced growth of $P$. italicum compared with control. The SC and SBC completely inhibited the linear growth at $2.0 \%$ causing $100 \%$ reduction.

B- In vivo:

Effect of single or combined applications of sodium carbonate (SC) or sodium bicarbonate (SBC) and citral on green mold severity of lime fruits

Sodium carbonate (SC) or sodium bicarbonate (SBC) at $2.0 \%$ alone or in combination with citral at $0.3 \%$ or $0.5 \%$ were tested under storage conditions to study their effect on green mould severity of lime fruits. Data in Table 3 indicate that all treatments have completely inhibited disease severity for one week of storage at $13 \pm 1^{\circ} \mathrm{C}$. 
Table 2: Effect of some components of volatile oil, sodium carbonate (SC) and sodium bicarbonate (SBC) on linear growth of Pencillium italicum

\begin{tabular}{|l|c|c|c|c|c|c|c|c|c|c|}
\hline \multirow{3}{*}{ Treatments } & \multicolumn{10}{|c|}{ Cinear growth (mm) } \\
\cline { 2 - 12 } & \multicolumn{8}{|c|}{ Concentration (\%) } \\
\cline { 2 - 12 } & $\mathbf{0 . 1}$ & $\mathbf{R \%}$ & $\mathbf{0 . 2}$ & $\mathbf{R} \%$ & $\mathbf{0 . 3}$ & $\mathbf{R} \%$ & $\mathbf{0 . 4}$ & $\mathbf{R} \%$ & $\mathbf{0 . 5}$ & $\mathbf{R} \%$ \\
\hline Citral & $35.0^{\mathrm{e}}$ & 61.1 & $17.5^{\mathrm{e}}$ & 80.6 & $6.5^{\mathrm{d}}$ & $\mathbf{9 2 . 8}$ & $0.0^{\mathrm{d}}$ & 100.0 & 0.0 & 100.0 \\
\hline Limonine & $51.5^{\mathrm{b}}$ & 42.8 & $27.5^{\mathrm{c}}$ & 69.4 & $15.3^{\mathrm{b}}$ & 83.0 & $6.7^{\mathrm{b}}$ & 92.6 & 0.0 & 100.0 \\
\hline Linalool & $43.5^{\mathrm{e}}$ & 51.7 & $23.5^{\mathrm{c}}$ & 73.9 & $12.0^{\mathrm{c}}$ & 86.7 & $4.8^{\mathrm{c}}$ & 94.7 & 0.0 & 100.0 \\
\hline Nerol & $25.5^{\mathrm{f}}$ & 71.7 & $13.5^{\mathrm{g}}$ & 85.0 & $5.3^{\mathrm{e}}$ & 94.1 & $0.0^{\mathrm{d}}$ & 100.0 & 0.0 & 100.0 \\
\hline & 0.5 & & 1.0 & & 1.5 & & 2.0 & & 3.0 & \\
\hline SC & $40.0^{\mathrm{d}}$ & 55.6 & $15.7^{\mathrm{f}}$ & 82.6 & 4.5 & 95.0 & $0.0^{\mathrm{d}}$ & 100.0 & 0.0 & 100.0 \\
\hline SBC & $42.3^{\mathrm{c}}$ & 53.0 & $20.7^{\mathrm{d}}$ & 77.0 & $5.6^{\mathrm{e}}$ & 93.8 & $0.0^{\mathrm{d}}$ & 100.0 & 0.0 & 100.0 \\
\hline \multicolumn{1}{|c|}{ Control } & $90.0^{\mathrm{a}}$ & & $90.0^{\mathrm{a}}$ & & $90.0^{\mathrm{a}}$ & & $90.0^{\mathrm{a}}$ & & $90.0^{\mathrm{a}}$ & \\
\hline
\end{tabular}

R= Reduction

Values having the same letters in the same column are not significantly different at $\mathrm{P}<0.05$

Data in Table 3 also indicated that combined treatment between citral and SC or SBC have significantly reduced the lime rot severity. The most effective treatments were combined treatment between citral at $0.5 \%$ and SC or SBC at $2 \%$ which completely inhibited the disease severity after two or three weeks storage, while single treatments of each concentration of SC or SBC at $2 \%$ and citral at $0.5 \%$ reduced disease severity more than $75.1 \%$ and $82.1 \%$ after two or three weeks, respectively. Generally all treatments decreased disease severity during storage up to three weeks compared to control. High efficacy was obtained with citral at $0.5 \%$ combined with SC or $\mathrm{SBC}$ at $2 \%$ during storage at $13 \pm 1{ }^{\circ} \mathrm{C}$ for three weeks.

Table 3: Effect of sodium carbonate (SC) or sodium bicarbonate (SBC) applied as single or in combination with citral on green mold severity of lime fruits during storage at $13 \pm 1^{\circ} \mathrm{C}$ for 3 weeks

\begin{tabular}{|c|c|c|c|c|c|c|}
\hline \multirow[b]{3}{*}{ Treatments } & \multicolumn{6}{|c|}{$\begin{array}{l}\text { Disease severity (\%) } \\
\text { Green mold }\end{array}$} \\
\hline & \multicolumn{2}{|c|}{1} & \multicolumn{2}{|c|}{2} & \multicolumn{2}{|c|}{3} \\
\hline & D.S & $\mathbf{E}$ & D.S & $E$ & D.S & $E$ \\
\hline \multicolumn{7}{|l|}{ Single treatment } \\
\hline Citral $0.3 \%$ & $0.0^{\mathrm{b}}$ & 100.0 & $8.9^{b}$ & 75.1 & $12.7^{b}$ & 83.2 \\
\hline Citral $0.5 \%$ & $0.0^{\mathrm{b}}$ & 100.0 & $4.9^{e}$ & 86.2 & $7.7^{\mathrm{d}}$ & 89.8 \\
\hline $\mathrm{SC} 2 \%$ & $0.0^{\mathrm{b}}$ & 100.0 & $7.7^{c}$ & 78.4 & $10.9^{c}$ & 85.6 \\
\hline SBC $2 \%$ & $0.0^{\mathrm{b}}$ & 100.0 & $8.3^{\mathrm{bc}}$ & 76.8 & $13.5^{\mathrm{b}}$ & 82.1 \\
\hline \multicolumn{7}{|l|}{ Combined Treatments } \\
\hline Citral $0.3 \%+$ SC $2 \%$ & $0.0^{\mathrm{b}}$ & 100.0 & $6.2^{\mathrm{d}}$ & 82.6 & $9.5^{\mathrm{c}}$ & 87.4 \\
\hline Citral $0.5 \%+$ SC $2 \%$ & $0.0^{\mathrm{b}}$ & 100.0 & $0.0^{\mathrm{g}}$ & 100.0 & $0.0^{f}$ & 100.0 \\
\hline Citral $0.3 \%+$ SBC $2 \%$ & $0.0^{\mathrm{b}}$ & 100.0 & $3.6^{f}$ & 89.9 & $5.8^{\mathrm{e}}$ & 92.3 \\
\hline Citral $0.5 \%+$ SBC $2 \%$ & $0.0^{\mathrm{b}}$ & 100.0 & $0.0^{9}$ & 100.0 & $0.0^{f}$ & 100.0 \\
\hline Control & $15.5^{\mathrm{a}}$ & & $35.7^{\mathrm{a}}$ & & $75.6^{\mathrm{a}}$ & \\
\hline
\end{tabular}

Values having the same letters in the same column are not significantly different at $P<0.05$

D.S = Disease severity $\quad$ E= Efficacy 
Effect of single or combined application of sodium carbonate (SC) or sodium bicarbonate (SBC) and citral on blue mold severity of lime fruits:

Data in Table 4 indicated that the most effective treatments were citral at $0.5 \%$ combined with SC or SBC at $2 \%$. On the other hand all treatments have completely inhibited disease severity of blue mold after one week, while after two or three weeks, it was completely inhibited with the combined treatment citral at $0.5 \%$ with SC or SBC at $2 \%$ and efficacy reached $100 \%$ during the cold storage at $13 \pm 1{ }^{\circ} \mathrm{C}$. The combined treatment has significantly reduced the disease severity after two weeks.

Table 4: Effect of sodium carbonate (SC) or sodium bicarbonate (SBC) applied as single or in combination with citral on blue mold severity of lime fruits during storage at $13 \pm 1^{\circ} \mathrm{C}$ for 3 weeks

\begin{tabular}{|c|c|c|c|c|c|c|}
\hline \multirow[b]{3}{*}{ Treatments } & \multicolumn{6}{|c|}{$\begin{array}{c}\text { Disease severity (\%) } \\
\text { Blue mold }\end{array}$} \\
\hline & \multicolumn{2}{|c|}{1} & \multicolumn{2}{|c|}{2} & \multicolumn{2}{|c|}{3} \\
\hline & D.S & $\mathbf{E}$ & D.S & $E$ & D.S & $E$ \\
\hline \multicolumn{7}{|l|}{\begin{tabular}{|l|} 
Single treatment \\
\end{tabular}} \\
\hline Citral $0.3 \%$ & $0.0^{\mathrm{b}}$ & 100.0 & $7.1^{\mathrm{c}}$ & 83.6 & $10.9^{d}$ & 85.9 \\
\hline Citral $0.5 \%$ & $0.0^{\mathrm{b}}$ & 100.0 & $5.3^{d}$ & 87.7 & $8.9^{e}$ & 88.6 \\
\hline SC $2 \%$ & $0.0^{\mathrm{b}}$ & 100.0 & $8.9^{b}$ & 79.4 & $12.9^{c}$ & 83.4 \\
\hline SBC $2 \%$ & $0.0^{\mathrm{b}}$ & 100.0 & $9.2^{b}$ & 78.7 & $15.1^{b}$ & 80.6 \\
\hline \multicolumn{7}{|l|}{ Combined Treatments } \\
\hline Citral $0.3 \%+$ SC $2 \%$ & $0.0^{\mathrm{b}}$ & 100.0 & $4.6^{e}$ & 89.4 & $7.7^{e}$ & 90.1 \\
\hline Citral $0.5 \%+$ SC $2 \%$ & $0.0^{\mathrm{b}}$ & 100.0 & $0.0^{\mathrm{d}}$ & 100.0 & $0.0^{g}$ & 100.0 \\
\hline Citral $0.3 \%+$ SBC $2 \%$ & $0.0^{\mathrm{b}}$ & 100.0 & $2.8^{f}$ & 93.5 & $6.2^{f}$ & 92.0 \\
\hline Citral $0.5 \%+$ SBC $2 \%$ & $0.0^{\mathrm{b}}$ & 100.0 & $0.0^{d}$ & 100.0 & $0.0^{\mathrm{g}}$ & 100.0 \\
\hline Control & $20.2^{\mathrm{a}}$ & & $43.2^{a}$ & & $77.8^{a}$ & \\
\hline
\end{tabular}

D.S=Disease severity E= Efficacy

Values having the same letters in the same column are not significantly different at $\mathrm{P}<0.05$

Effect of single or combined application of sodium carbonate (SC) or sodium bicarbonate (SBC) and citral on percentage of infection of lime fruits under natural infection

Data in Table (5) showed the effect of citral oil and SC or SBC with single or combined treatment on the percentage of infection under natural infection of lime fruits. All treatments have completely inhibited infection of lime fruits for one week of storage at $13 \pm 1^{\circ} \mathrm{C}$. High efficacy $100 \%$ was obtained from the single and the combined treatments at same storage period. The combined treatment significantly reduced disease severity after two or three weeks. The treatment combined with citral at $0.5 \%$ with SC and SBC at $2 \%$ completely inhibited infection percentage after three weeks of storage. 
Table 5: Effect of citral and sodium carbonate (SC) or sodium bicarbonate (SBC) applied as single or in combination on percentage of infection (Inf.\%) of lime fruits during 3 weeks1 $3 \pm$ $1^{\circ} \mathrm{C}$ under natural infection

\begin{tabular}{|c|c|c|c|c|c|c|}
\hline \multirow{3}{*}{\begin{tabular}{|lr}
$\begin{array}{r}\text { Storage period } \\
\text { (weeks) }\end{array}$ \\
Treatments
\end{tabular}} & \multicolumn{6}{|c|}{ Infection (inf.\%) } \\
\hline & \multicolumn{2}{|c|}{1} & \multicolumn{2}{|c|}{2} & \multicolumn{2}{|c|}{3} \\
\hline & Inf. $\%$ & $\mathbf{E}$ & Inf.\% & $\mathbf{E}$ & Inf.\% & $\mathbf{E}$ \\
\hline \multicolumn{7}{|l|}{ Single treatment } \\
\hline Citral $0.3 \%$ & $0.0^{\mathrm{b}}$ & 100.0 & $0.0^{\mathrm{b}}$ & 100.0 & $5.3^{c}$ & 85.2 \\
\hline Citral $0.5 \%$ & $0.0^{\mathrm{b}}$ & 100.0 & $0.0^{\mathrm{b}}$ & 100.0 & $1.8^{\mathrm{d}}$ & 94.9 \\
\hline SC $2 \%$ & $0.0^{\mathrm{b}}$ & 100.0 & $0.0^{\mathrm{b}}$ & 100.0 & $6.4^{\mathrm{b}}$ & 82.1 \\
\hline SBC 2\% & $0.0^{\mathrm{b}}$ & 100.0 & $0.0^{\mathrm{b}}$ & 100.0 & $5.8^{\mathrm{bc}}$ & 83.8 \\
\hline \multicolumn{7}{|l|}{ Combined treatments } \\
\hline Citral $0.3 \%+$ SC $2 \%$ & $0.0^{\mathrm{b}}$ & 100.0 & $0.0^{\mathrm{b}}$ & 100.0 & $1.8^{\mathrm{d}}$ & 94.9 \\
\hline Citral $0.5 \%+$ SC $2 \%$ & $0.0^{\mathrm{b}}$ & 100.0 & $0.0^{\mathrm{b}}$ & 100.0 & $0.0^{e}$ & 100.0 \\
\hline Citral $0.3 \%+$ SBC $2 \%$ & $0.0^{\mathrm{b}}$ & 100.0 & $0.0^{\mathrm{b}}$ & 100.0 & $2.2^{d}$ & 93.8 \\
\hline Citral $0.5 \%+$ SBC $2 \%$ & $0.0^{\mathrm{b}}$ & 100.0 & $0.0^{\mathrm{b}}$ & 100.0 & $0.0^{\mathrm{e}}$ & 100.0 \\
\hline Control & $7.5^{\mathrm{a}}$ & & $16.7^{\mathrm{a}}$ & & $35.7^{a}$ & \\
\hline
\end{tabular}

E= Efficacy

Values having the same letters in the same column are not significantly different at $P<0.05$

Effect of sodium carbonate or sodium bicarbonate applied as single or in combination with citral on some lime fruits quality under natural infection

All treatments lowered the loss in weight in fresh weight of lime fruits compared to control after three weeks of storage as shown in (Table 6). Combined treatments showed the lowest loss in lime fresh weight when compared with single treatment. The loss in weight reached the maximum after three weeks when SCB were used. TSS increased in all treatments compared to control as shown in (Table 6). Ascorbic acid (Vitamin C) was decreased in all treatments compared to the control in naturally infected lime fruits.

Table 6: Effect of citral and sodium carbonate (S.C) or sodium bicarbonate (SBC) on loss of lime fruits weight, total soluble solids (TSS) and vitamin C (VC) after 3 weeks storage at $13 \pm 1^{\circ} \mathrm{C}$ under natural infection

\begin{tabular}{|c|c|c|c|}
\hline Treatments & Loss in weight $\%$ & TSS (\%) & Vitamin C \\
\hline \multicolumn{4}{|l|}{ Single treatment } \\
\hline Citral $0.3 \%$ & 3.0 & 8.5 & 45.0 \\
\hline Citral $0.5 \%$ & 2.5 & 8.5 & 45.0 \\
\hline SC $2 \%$ & 3.7 & 9.0 & 44.0 \\
\hline SBC $2 \%$ & 4.0 & 9.0 & 43.0 \\
\hline \multicolumn{4}{|l|}{ Combined Treatment } \\
\hline Citral $0.3 \%+$ SC $2 \%$ & 2.7 & 9.2 & 45.0 \\
\hline Citral $0.5 \%+$ SC $2 \%$ & 2.2 & 9.2 & 44.0 \\
\hline Citral $0.3 \%+$ SBC $2 \%$ & 2.5 & 8.8 & 45.0 \\
\hline Citral $0.5 \%+$ SBC $2 \%$ & 2.0 & 8.5 & 45.0 \\
\hline Control & 6.6 & 7.5 & 46.0 \\
\hline
\end{tabular}




\section{DISCUSSION}

Postharvest green and blue molds caused by Penicillium digitatum and P.italicum are important postharvest storage problems of lime fruits (Smilanick and Arruf, 1992). Component of volatile oil i.e limonene, linalool, citral and nerol were extracted from orange peel, coriander fruits, lemon grass and petitgrain (Bitter orange) respectively, and used in this study. In vitro nerol and citral caused complete inhibition on linear growth of tested fungi at 0.4 and $0.5 \%$. Linalool gave the lowest effect on linear growth of the two fungi. The differences between component of each other and the antimicrobial characteristics seemed to be correlated with their structure, solubility and capacity to penetrate cell wall and to interfere with the enzymatic reaction of the cytoplasmic membrane (Knobloch et al., 1989).

Sodium carbonate has completely inhibited the mycelial growth at concentrations $2.0 \%$ and $3.0 \%$. These results are similar to those reported by Wassana (2004) who found that Sodium bicarbonate at $1 \%$ appear to inhibit growth of $P$. digitatum and their concentration at $2 \%$ and above could completely inhibit spore germination. Inhibition of microorganisms by salts might be caused by reducing of the cell turgor pressure with collapse and shrinkage of hypha and spore (Fallik et al., 1997) or by alteration of cell transport function and inhibition of enzymes involved in the glycol improved lytic pathway (Sofos et al., 1986).

Citral, sodium carbonate (SC) and sodium bicarbonate (SBC) were used in the present study against green and blue molds in vivo. Citral oil, SC and SBC were effective in controlling green and blue molds. The effectiveness is quiet good when applied as single, but improved when used in combination. Citral at $0.5 \%$ inhibited percentage disease severity of lime fruits under artificial infection condition with $P$. digitatum and $P$. italicum and percentage of infection under natural infection condition. Using citral for controlling postharvest disease of oranges as reported by Abd-El-kareem and Abd-Alla (2002). The mechanism of citral in reducing postharvest disease appears to be related to fungistatic property (Rodove et al., 1985). Treatment of lime fruits with SC and SBC when applied as single treatment reduced fungal infection and delayed disease development under artificial infection during storage up to three weeks. Effective control of green and blue molds of lime fruits by combined treatment between citral at $0.5 \%$ and SC or SBC at $2.0 \%$. High efficacy $100 \%$ was obtained at the same treatment. The inhibitory effect of SC or SBC depends on the presence of salt residues within the wound infection courts occupied by the fungus and on interactions between this residue and constituents of the rind. These interactions presumably alter the original in vitro toxicity of the salts to spores. All treatments lowered the loss in fresh weight of lime fruits during storage in naturally infected fruits compared to control. Total soluble solids and vitamin C decreased at all treatment compared to control. Sami et al. (2007) reported that the loss was decreased in fresh weight of lime fruit and increased in TSS under natural infection during storage at $13^{\circ} \mathrm{C}$ for four weeks. 


\section{REFERENCES}

Abd-El-Kareem, F. and M.A. Abd-Alla, (2002): Citral for controlling postharvest disease of noval orange fruits. Egypt J. Appl. Sci., 17: 238256

Abd- El- Kareem, F. (2007): Potassium or sodium bicarbonate in combination with Nerol for controlling early blight disease of potato plants under laboratory, greenhouse and field conditions Egypt. J. Phytopathol., 35: 73-86

British Pharmacopoeia (1963): Determination of Volatile Oil in Drugs. The Pharmaceutical Press, London.

Caccioni, D.R.L.; M. Guizzardi; D.M. Biondi; A. Renda and G. Ruberrto (1998): Relationship between volatile compounds of citrus fruit essential oils and antimicrobial action on Penicillium digitatum and $P$. italicum. International J. of Food Microbiol., 43: 73- 79

Carlson, L.H.C.; R.A.F Machado; C.B. Spricigo; L.K. Pereira and A. Bolzan (2001): Extraction of lemongrass essential oil with dense carbon dioxide. J. Supercritical Fluids. 21: 33-39.

Droby, S.; A. Eick; D. Macarisim; L. Cohen; G. Rafael; R. Stange; G. McColum; N. Dudai; A. Nasser; M. Wisniewski and R. Shadira (2008): Role of citrus volatiles in host recognition, germination and growth of Penicillium digitatum and Penicillium italicum. Postharvest Biol. and Tech. 49: 386 - 396.

Fallik, E.; S. Grinberg and O. Ziv (1997): Potassium bicarbonate reduces postharvest decay development reduces postharvest decay development on bell pepper fruits. J. Hort. Sci. 72: $35-41$.

Hanounik, S.B. (1986): Screening Techniques for disease resistance in faba bean. International Center Acricultural Research in the dry areas (ICARDA). Aleppo, Syria. 59 PP.

Jemey, E. and E. Kovacs (1968): Investigation of vitamin C content of fruits and vegetables. Elemizervizs galati. Kozlemenyek, 15: 3-8.

Kamel, M.; H. Karim; B. Mouna; T. Taarit; M. Chahed; K. Elyes and M Brahim (2007): Changes on essential oil composition of coriander (Coriandrum sativum L.) fruits during three stages of maturity. Food Chemistry, 102: $1131-1134$

Knobloch, K.; A. Pauli; B. Iberl; N. Weis and Weigand (1989): Antimicrobial and antifungal properties of oil compounds. J. Essent. Oil Res. 1: 119128.

Latifa, A.; T. Idriss; B. Hassan; S.M. Amine; B. El-Hassane and A.B.A. Abdella (2011): Effect of organic acids and salts on the development of Penicillium italicum, the causal agent of citrus blue mold. Plant Pathol. T. 10: $99-107$.

Lee, H.S. and Y.J. Ahn (1998): Growing-inhibiting effects of Cinnamomum cassia bark derived materials on human intestinal bacteria. J. Agric. Food Chem. 46: 8-12.

MSTAT-C v.2. (1988): A microcomputer program for design, Management, and analysis of Agronomic Res. Exp. Michigan State Univ., U. S. A. 
NIIR BOARD (2003): The Complete Technology Book of Essential Oils (Aromatic Chemicals), 1st edd. Pub: National Institute of Industrial Research (NIIR) Asia Pacific Business Press Inc, ISBN-10: 8178330660, pp, 597-598.

Palou, L.; J.L. Smilanick; J. Usall and I. Vinas (2001): Control of blue and green molds of oranges by hot water, sodium carbonate, and sodium bicarbonate. Plant Dis. 85: $371-376$.

Palou, L.; J.L. Smilanick and Crisosto (2009): Evaluation of food additives as alternatives or complementary chemicals to conventional fungicides for the control of major postharvest diseases of stone fruits. J. Food Port., 147: $1037-1046$.

Raper, K.B. and C. Tom (1968): A Manual of Penicillia. Hafiner Publishing, Co., Inc., New York

Rodove, V.; S. Ben-yehoshua; D.Q. Fan; J.J. Kim and R. Ashkenaza (1985): Performed antifungal compounds of lemon fruits. : Citral and its relation to disease resistance. J. Agric. Food Chem., 43: 1057-1061.

Sami., H.M.; R.H. Mervat and M.N. Azz (2007): Control of green and blue mould of lemon fruits by postharvest treatments. Eleven Congress of Phytopathology , Giza, Eygypt, pp 226-237.

Schaneberg, B.T; and I.A. Khan (2002): Comparison of extraction methods for marker compounds in the essential oil of lemongrass by GC. J. Agric. Food Chem. 50: 1345-1349.

Smilanick, J.L. and R.D. Arruf (1992): Control of green mould of lemons with Pseudomonas species. Plant Dis.5: $481-485$.

Smilanick, J.L.; B.E. Mackey; R. Reese; J. Usall and D.A. Margosan (1997): Influence of concentration of soda ash, temperature, and immersion period on the control of postharvest green mold of oranges. Plant Dis 81: $379-382$.

Sofos, J.N.; M.D. Pierson; J.C. Blocher and F.F. Busta (1986): Mode of action of sorbic acid on bacterial cells and spores. Int. J. Food Microbiol., 3: 1 $-17$.

Wassana (2004): Effect of chemical salts and coating materials on postharvest quality of mandarin cv. Sai Nam pung. M. Sc. Thesis, Fac. Scie., Chiang Mai Univ., Thailand. 92 p. 


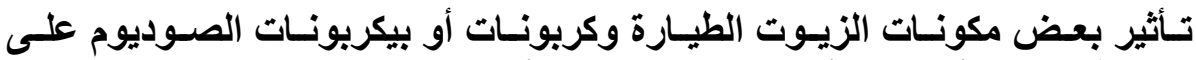

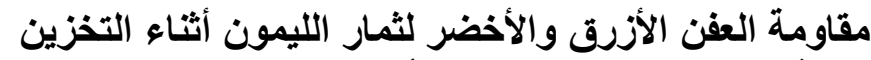

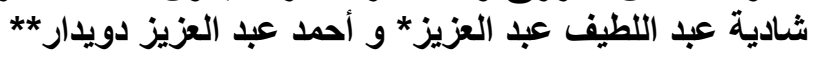

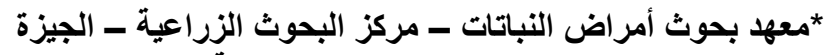

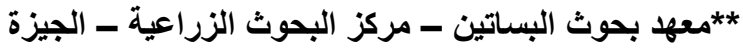

تم إستخلاص بعض مكونـات الزيوت الطيارة و وهي السيتر ال و الليمونين و اللينـالول

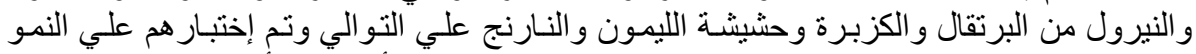

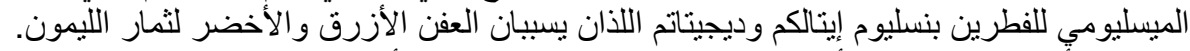

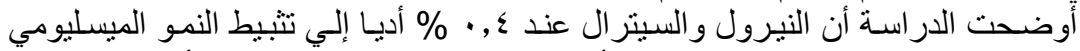

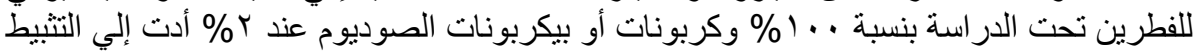
الكامل لنمو الفطرين.

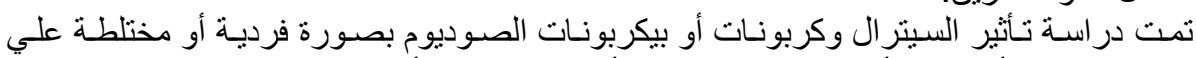

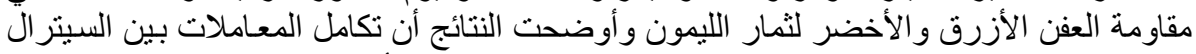

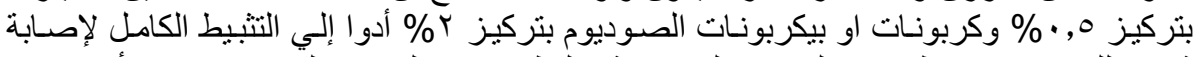

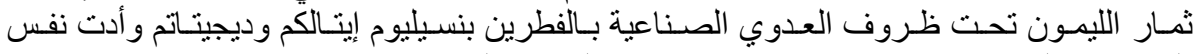

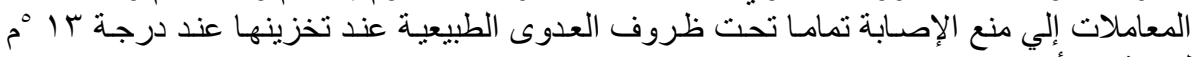

وبتقدير الجودة للثمار أثناء التخزين وجد أنة قد قل الوزن الطازج لثمار الليمون ومحتو اها لمدة ثلاث أسابيع. من فيتامين C بينما زادت نسبة المواد الصلبة الصلبة الكلية.

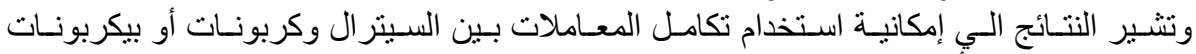
الصوديوم لمقاومة أمر اض ما بعد الحصاد لثمار الليمون.

كلية الزراعة - جامعة المنصورة كلية الزراعة - جامعة بنها

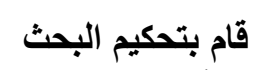

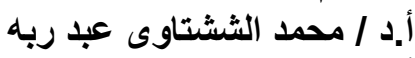
أ.د / نوال عبد المنعم حسن المن ريدائ 